San Jose State University

SJSU ScholarWorks

Master's Theses

Master's Theses and Graduate Research

1990

\title{
Effects of chronic alcohol consumption on the cerebral cortex of rats using immunocytochemistry of alcohol dehydrogenase
}

Michele Lynn Cherry

San Jose State University

Follow this and additional works at: https://scholarworks.sjsu.edu/etd_theses

\section{Recommended Citation}

Cherry, Michele Lynn, "Effects of chronic alcohol consumption on the cerebral cortex of rats using immunocytochemistry of alcohol dehydrogenase" (1990). Master's Theses. 3306.

DOI: https://doi.org/10.31979/etd.bt4r-tw85

https://scholarworks.sjsu.edu/etd_theses/3306

This Thesis is brought to you for free and open access by the Master's Theses and Graduate Research at SJSU ScholarWorks. It has been accepted for inclusion in Master's Theses by an authorized administrator of SJSU ScholarWorks. For more information, please contact scholarworks@sjsu.edu. 


\section{INFORMATION TO USERS}

The most advanced technology has been used to photograph and reproduce this manuscript from the microfilm master. UMI films the text directly from the original or copy submitted. Thus, some thesis and dissertation copies are in typewriter face, while others may be from any type of computer printer.

The quality of this reproduction is dependent upon the quality of the copy submitted. Broken or indistinct print, colored or poor quality illustrations and photographs, print bleedthrough, substandard margins, and improper alignment can adversely affect reproduction.

In the unlikely event that the author did not send UMI a complete manuscript and there are missing pages, these will be noted. Also, if unauthorized copyright material had to be removed, a note will indicate the deletion.

Oversize materials (e.g., maps, drawings, charts) are reproduced by sectioning the original, beginning at the upper left-hand corner and continuing from left to right in equal sections with small overlaps. Each original is also photographed in one exposure and is included in reduced form at the back of the book.

Photographs included in the original manuscript have been reproduced xerographically in this copy. Higher quality $6 " \times$ " 9 " black and white photographic prints are available for any photographs or illustrations appearing in this copy for an additional charge. Contact UMI directly to order.

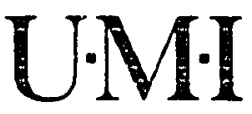

University Microfilms International

A Bell \& Howell Information Company

300 North Zeeb Road. Ann Arbor. MI 48106-1346 USA

313/761.4700 800/521.0600 
Effects of chronic alcohol consumption on the cerebral cortex of rats using immunocytochemistry of alcohol dehydrogenase

Cherry, Michele Lynn, M.A.

San Jose State University, 1990 

NOTE TO USERS

THE ORIGINAL DOCUMENT RECEIVED BY U.M.I. CONTAINED PAGES WITH PHOTOGRAPHS WHICH MAY NOT REPRODUCE PROPERLY.

THIS REPRODUCTION IS THE BEST AVAILABLE COPY. 

EFFECTS OF CHRONIC ALCOHOL CONSUMPTION

ON THE CEREBRAL CORTEX OF RATS

USING IMMUNOCYTOCHEMISTRY OF ALCOHOL DEHYDROGENASE

\author{
A Thesis \\ Presented to \\ The Faculty of the Department of Biology \\ San Jose State University
}

\author{
In Partial Fulfillment \\ of the Requirements for the Degree \\ Master of Arts
}

\author{
by \\ Michele Iynn Cherry \\ August, 1990
}




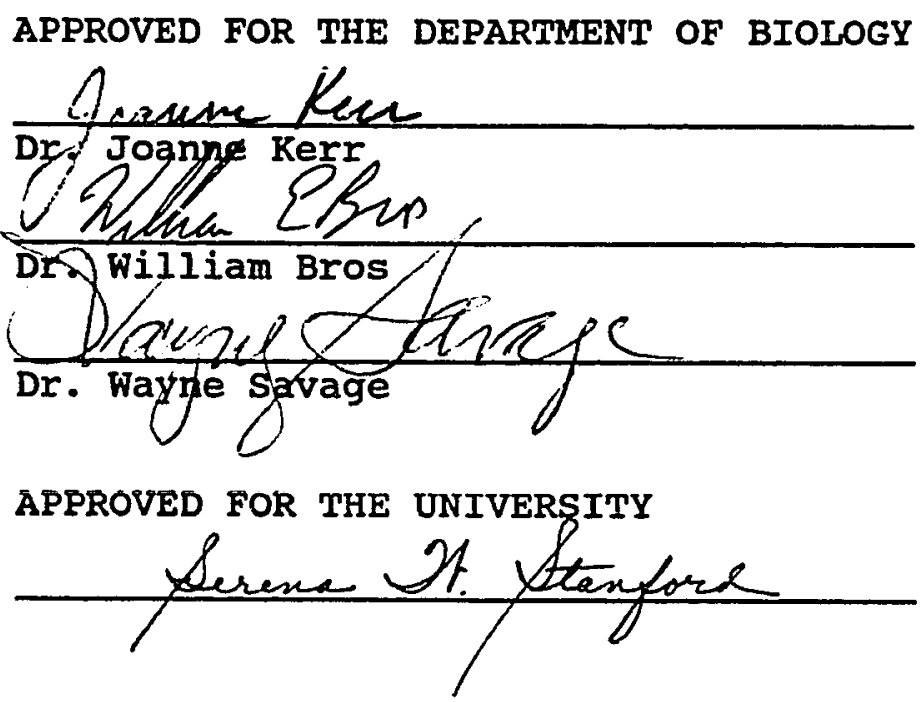




\section{ABSTRACT}

EFFECTS OF CHRONIC ALCOHOL CONSUMPTION

ON THE CEREBRAL CORTEX OF RATS

USING IMMUNOCYTOCHEMISTRY OF ALCOHOL DEHYDROGENASE

by Michele I. Cherry

This thesis measured the effects of chronic alcohol administration on the pattern of alcohol dehydrogenase ( $A D H$ ) distribution in the prefrontal and premotor regions of the rat cerebral cortex. The study employed immunocytochemistry to stain for $A D H$ and a computer assisted analysis to determine the density of $\mathrm{ADH}$-containing neurons in the cerebral cortex. From this study it was shown that the density of $\mathrm{ADH}$-containing neurons did not differ between rats that consumed alcohol and those that received a liquid control or chow diet.

In addition to these findings was the discovery of ADH within the axons of ADH-containing Betz cells. Axons that stained for $\mathrm{ADH}$ were found among all three diet groups. Before this study ADH had not been consistently found in neuronal axons. These results have generated new ideas and new plans for future experiments in alcohol research. 


\section{ACRNOWLEDEEMENTS}

I am especially indebted to Dr. Joanne Kerr for her assistance and knowledge in alcohol research which guided me through this project. I would like to thank Dr. William Bros for his computer expertise that made determining cell density of the tissue sections relatively easy and for the time he spent helping me with the computer graphics. I also want to express my appreciation to $\mathrm{Dr}$. Wayne Savage for agreeing to be part of $\mathrm{my}$ thesis committee.

Others I would like to thank include Jesse Martinez and his staff for overseeing the animal care facilities, Shawn Burns for helping in the daily feeding of the animals, Eric Messner who assisted in sacrificing the animals, and Jeff Kalousdian and Roland Ruby for being part of the laboratory team. 


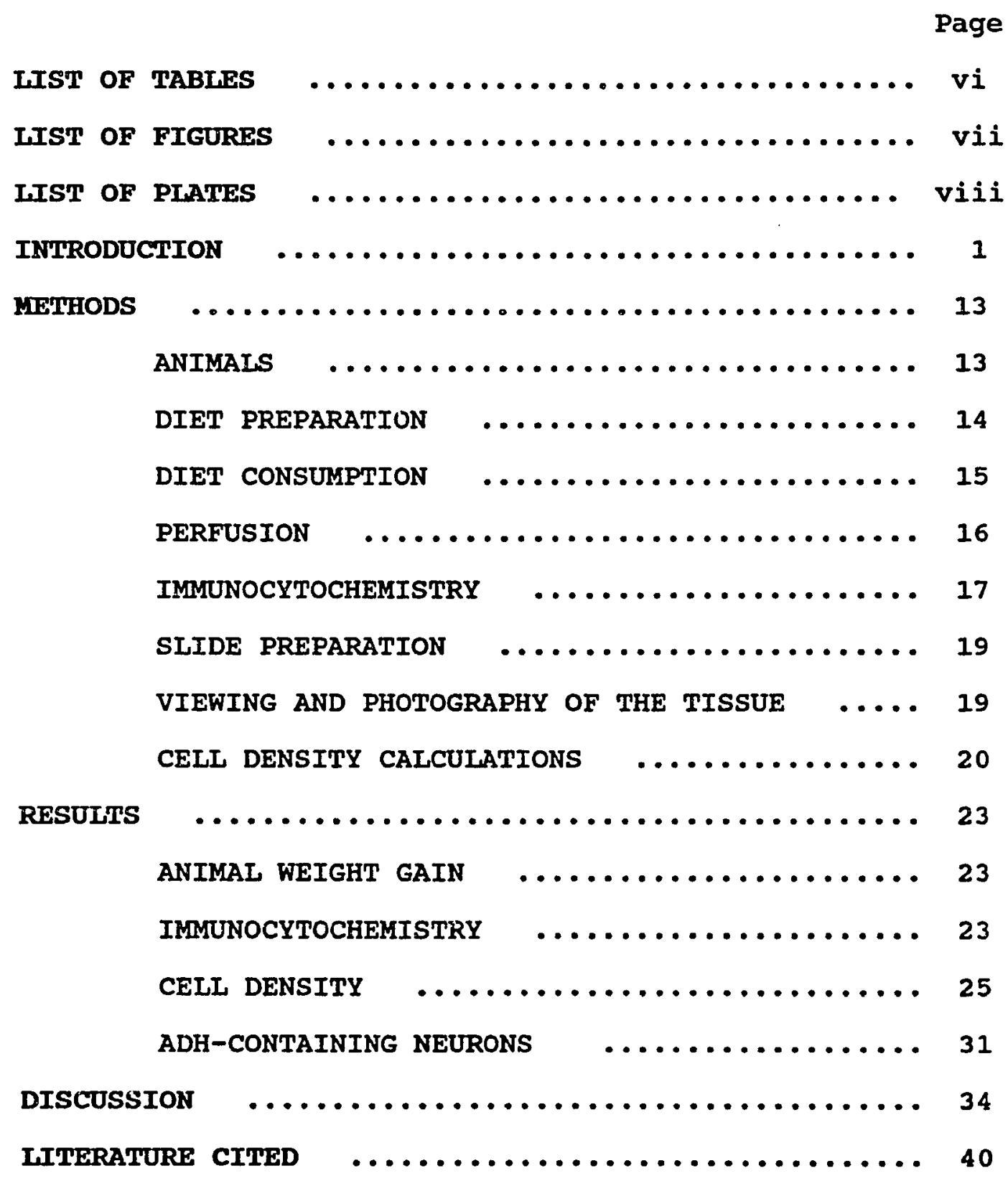




\section{TABLES}

Table

Page

1. Average Weight in Grams and Percent Weight Gain for Each Diet Group During the 159 Day study

2. Nested Analysis of Variance 30 


\section{FIGURES}

Figure

Page

1. The Metabolic Pathway of Ethanol Elimination From the Body

vii 


\section{PLATES}

Plate Page

1. Computer Generated Analysis for the Location of ADH-Containing Neurons in the Cerebral cortex of a Liquid Diet Animal $\ldots \ldots \ldots \ldots \ldots \ldots \ldots . . \ldots 21$

2. Cerebral Cortex - Preimmune Serum on a Liquid Diet Control Section ..... 26

3. Cerebral Cortex - Liquid Diet Control .. 27

4. Cerebral Cortex - Ethanol Liquid Diet .. 28

5. Cerebral Cortex - Chow Control Diet .... 29

6. Cerebral Cortex - ADH-Containing Axon of an ADH-Containing Betz Cell ..... 33 


\section{INTRODUCTION}

Alcohol is an addictive, psychoactive drug capable of producing social, economic, and health problems (Mendelson and Mello, 1979; Lieber, 1983). It has been estimated, that in the United States, $\$ 117$ billion dollars are spent annually to cover the loss of human productivity and various health expenses created by alcohol (Charness, et al., 1989). Alcohol acts as a central nervous system (CNS) depressant and is capable of producing dramatic medical complications including liver dysfunction, gastrointestinal problems, nutritional deficiencies, endocrine, cardiac, and hematological complications as well as various neurological disorders (Lieber, 1983). Moderate amounts of ethanol have been shown to increase high density lipoproteins (HDL), which may reduce the risk of cardiovascular disease (Schuckit, 1984), but when consumed in large amounts, alcohol acts as an anesthetic, effecting the reticular activating system and the frontal cortex (Wallgren, 1966).

An alcohol abuser may not always display evidence of neurological disorders. The reasons for variation in the pathologies of alcoholism are complex and at present not completely understood. When neurological disorders are present, they represent a diverse and devastating subset of the medical complications created by alcohol. The Wernicke- 
Korsakoff syndrome is one example of a neurological disorder that affects some chronic alcoholics.

In 1881, Carl Wernicke described three fatal cases of what he considered to be an acute superior hemorrhagic polioencephalitis. Of the three patients, two fatalities were in alcoholic men and the third patient died of sulfuric acid poisoning (Victor, et al., 1971). These patients showed impairment of consciousness, ataxia, ocular palsies, neuropathological lesions in the mammillary bodies, and generalized atrophy of the cerebral hemispheres (De Wardener and Lennox, 1947).

S.S. Korsakoff (1887) described an amnesia syndrome, characterized by impaired learning abilities and memory defects, including delirium, anxiety, fear, and depression (Ron, 1982; Victor, et al., 1971). This syndrome was given the name psychosis polyneuritica. Korsakoff recognized the relationship between the psychic symptoms of this disease process and the psychic symptoms that accompany alcoholic polyneuropathy. He proposed that the disease he described resulted from exposure to a noxious substance which disturbed the nutritional status of the CNS (Victor, et al., 1971).

Victor, Adams and Collins (1971) studied 186 patients with Wernicke's disease and found 157 (or 84 percent) of the 
patients to be suffering from Korsakoff's psychosis. The connections made between the two disorders prompted a unification of Wernicke's disease and Korsakoff's psychosis. The term victor and his colleagues used to collectively describe the observed neurological disorders was the Wernicke-Korsakoff syndrome.

The exact cause for the development of WernickeKorsakoff disease has been the subject of much debate among scientists. De Wardener and Lennox (1947) reported that Wernicke's encephalopathy was caused by a deficiency of thiamine in the body. Victor, et al., (1971) concluded that ethanol and thiamine act synergistically to produce the cerebral damage present in Wernicke-Korsakoff syndrome.

It has been shown that ethanol abuse is capable of producing various nutritional deficiencies, which can result in neurological problems, by altering the balance of nutrients in the body (Neville, et al., 1968; Thomson, 1978). The cNS requires a constant supply of oxygen and nutrients, such as glucose, amino acids, vitamins and trace elements for energy (Thomson, 1982). The brain, which accounts of 25-30 per cent of the body's basal metabolic rate, is unable to store energy (Sokoloff, et al., 1977). with chronic ethanol consumption, there may be impaired nutrient absorption from the digestive system, as well as 
reduced hepatic storage of thiamine and disturbances in thiamine intake (Inokuchi, et al., 1981; Lieber, 1983; Thomson, et al., 1983). A consequence of thiamine deficiency is a reduction of glucose utilization by the brain (Schenker, et al., 1980). The lack of thiamine can affect three cerebral enzymes (transketolase, pyruvate decarboxylase and alpha-ketoglutarate decarboxylase) which function in the conversion of glucose to fatty acids used in neuronal myelination or energy production (McCandless, et al., 1976; Schenker, et al., 1980).

If the high metabolic demands of the brain are not met, lesions may occur resulting in the symptoms seen among Wernicke-Korsakoff patients (Inokuchi, et al., 1981; Thomson, et al., 1983). Biochemical lesions in the brain due to thiamine deficiency may respond to thiamine replacement therapy. If the lesions are structural, rather then biochemical, symptoms associated with WernickeKorsakoff syndrome may be reversed slowly or incompletely with thiamine replacement therapy (Charness, et al., 1989; De Wardener and Lennox, 1947; Victor, et al., 1971). Histological lesions of the cerebral cortex have been documented in Wernicke-Korsakoff syndrome. In Victor's, et al., (1971) study, 50 percent of the patients showed histological lesions and degeneration of the cerebral 
cortex.

Through the use of computer assisted topography (CAT) scanning, it has been demonstrated that with chronic alcohol exposure the lateral ventricles may enlarge and the sulci of the frontal cortex widen due to tissue atrophy (Ron, 1982; Thomson, et al., 1983). On a microscopic level, these lesions can be attributed to cell loss with disruption of the cortical laminae, proliferation of the glial elements, and pigmentary degeneration (Corvelli, 1955).

Other work on Korsakoff's psychosis has shown that ethanol ingestion may cause a degeneration of cholinergic neurons in the basal forebrain (Arendt, et al., 1987; Arendt, et al., 1988). These neurons are known to supply the cerebral cortex and hippocampus. Degeneration is an irreversible process that will ultimately result in memory impairment (Arendt, et al., 1987).

There are many theories regarding the pathology associated with Wernicke-Korsakoff syndrome, but the causes of the disease still remain unsolved. It is known that the body has the physiological capability to metabolize alcohol. However, when alcohol is consumed in excess or over long periods of time, the extent to which the body can metabolize the alcohol may be altered. 
The physiological component principally responsible for alcohol metabolism in mammals is the enzyme alcohol dehydrogenase (ADH) (Julia, et al., 1987). ADH is located in the cytoplasm and mitochondria of select cells. The enzyme functions as a catalyst in the oxidation of alcohol to acetaldehyde (Figure 1). Acetaldehyde, a toxic byproduct of the reaction, is further metabolized to acetate through acetaldehyde dehydrogenase (ALDH) . Both ADH and ALDH require nicotinamide adenine dinucleotide $\left(\mathrm{NAD}^{+}\right)$to perform the oxidation reactions. Pathological findings associated with prolonged ethanol ingestion have been attributed to the production of acetaldehyde in the body. Acetaldehyde has been shown to cause impairment of myocardial protein synthesis, inhibition of oxidative phosphorylation, acute flushing response in humans, condensation reactions with biogenic amines that may produce a dependence reaction toward alcohol; acetaldehyde may also be responsible for some of the developmental abnormalities seen in children with Fetal Alcohol Syndrome (Abel, 1982; Jones, et al., 1973; Kissin and Begleiter, 1983; Korsten, et al., 1975; Schreiber, et al., 1974; Westcott, et al., 1980; Zeiner, et al., 1979).

Early investigations of alcohol metabolism have shown that $90 \%$ of the metabolism occurs within the liver through the action of $\mathrm{ADH}$ and other minor pathways 


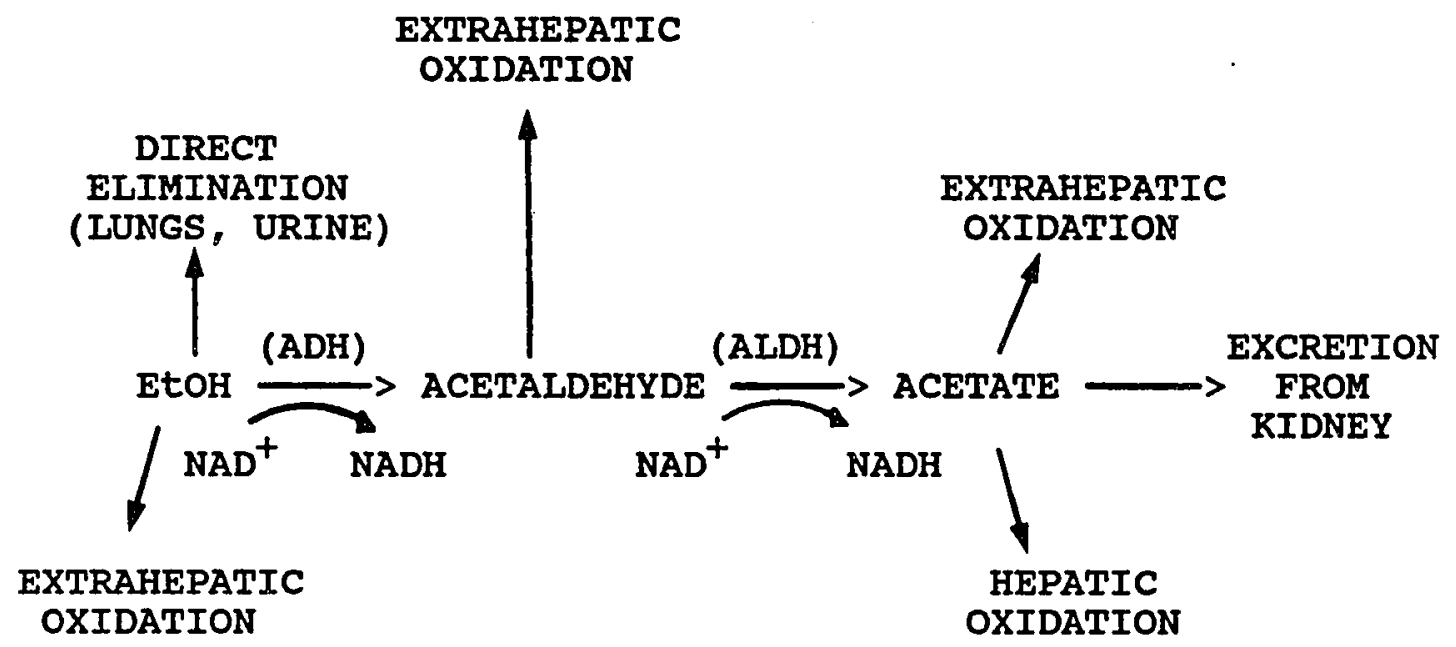

Figure 1: The metabolic pathway of ethanol elimination from the body

(Majchrowicz and Nobel, 1979). 
(Jacobsen, 1952). Additional locations responsible

for alcohol metabolism include the retina, stomach, lung, adrenal glands, the kidney nephron proximal tubule cells and the brain (Goldstein and Maxwell, 1982; Julia, et al., 1987; Kerr, et al., 1989a). In these organs, the presence of $\mathrm{ADH}$ has been determined either through biochemical enzyme assays or the use of immunocytochemistry.

Previous studies of the rat have examined ADH activity levels using whole brain homogenates (Duncan, et al., 1976; Raskin and Sokoloff, 1970; Tabakoff and von Wartburg, 1975). The homogenates were used in assays that utilized the oxidative potential of $\mathrm{ADH}$ to reduce L-lactaldehyde to propanediol coupled to the ethanoldependent generation of NADH (Raskin and Sokoloff, 1970). Whole brain homogenates were examined because ADH was presumed to be located throughout both the white and gray matter that compose the brain. In these studies, only low levels of ADH activity were detected and it was concluded that $A D H$ was not a significant factor in alcohol metabolism within the brain and has little importance in the brain following ethanol administration (Duncan, et al., 1976; Raskin and Sokoloff, 1970; Tabakoff and von Wartburg, 1975). The discovery by Duncan, et al., (1976) supported the theory that $\mathrm{ADH}$ was not important in metabolizing 
alcohol in the brain. Duncan and his colleagues showed that $10 \%$ of the total ADH activity in the brain $(<1 \mathrm{mg} / \mathrm{dl})$ was contained within the blood capillaries and not within the brain tissue. The results from Raskin and Sokoloff (1970), Tabakoff and von Wartburg (1975) and Duncan, et al., (1976) have left many unanswered questions regarding the CNS effects of alcohol and most especially the effects seen following chronic alcohol abuse such as in WernickeKorsakoff synarome.

Current research, conducted by Kerr, et al. (1989a), has shown that $A D H$ is localized in specific brain regions and limited to particular cell population. Using a modification of sternberger's method of immunocytochemistry (Sternberger, 1974), Kerr localized the ADH antigen in the brain through the sequential addition of excess unlabeled antibodies. By using unlabeled antibodies, rather then enzymes, a specific antibody combining property involving covalent bonding can be employed (Sternberger, 1974). The use of excess antibody assures that the antibodies with the strongest avidities will bind to the antigen, while the weaker antibodies will remain in solution and dissociation of the bound antibodies is, therefore, minimized. The sensitivity of this model is very high because the addition of antibody in excess generally supports the theory that the 
antibody will bind at both of the antigen's specific binding sites. Visualization of the antibody-antigen complex is done by using another antibody that binds to the complex and is be detectable with a specific histochemical substrate (Sternberger, 1974). In Kerr's study and the present study, $\mathrm{ADH}$ was identified in neurons of the frontal cortex, mammillary bodies, periaqueductal gray, and in the Purkinje cells of the cerebellum.

The purpose of this thesis was to measure the effects of chronic alcohol administration on the pattern of ADH distribution in the prefrontal and premotor regions of the rat cerebral cortex. The rat cerebral cortex is divided into three regions: prefrontal, premotor and the motorsensory cortex. Only the prefrontal and premotor cortices were investigated in this study in order to determine the effect ethanol has on the neurons responsible for behavior and motor activities. The prefrontal cortex is concerned with higher mental functions (i.e., intellect and memory) and related behavioral factors (i.e., judgement). The premotor cortex initiates activation and performance of motor activities and receives primary sensations from the body.

There are three classifications of neurons in the cerebral cortex and they are divided between six cellular 
layers. The three classes of neurons include the interneurons, the association neurons, and the efferent neurons. The interneurons have axons that do not leave the frontal cortex; the association neurons send their axons through the white matter to other regions of the cortex; and the efferent neurons have axons that leave the cortex to innervate structures in the brain stem or spinal cord. The efferent neurons also have collateral axons that project to nearby cortical neurons for association. The cellular layers, as they appear from the external portion of the brain inward, include: plexiform (molecular), outer granular, pyramidal, inner granular, ganglionic and multiform layers. Examination of the cerebral cortex was conducted in order to better understand the damage excessive alcohol consumption has on this brain region. The density of stained neurons in the cerebral cortex was calculated in this thesis study. The density calculations provide a way to analyze the distribution of ADH-containing neurons per square millimeter of tissue among three groups of rats that differed in the type of diet they consumed. The effects of chronic alcohol consumption on $\mathrm{ADH}-$ containing neurons were determined by comparing $\mathrm{ADH}$ neuron density among animals that received the Bioserv ${ }^{T M}$ liquid diet with ethanol (i.e., the experimental group), the 
Bioserv ${ }^{\mathrm{TM}}$ isocaloric liquid diet (i.e., liquid diet control group), and the solid diet control group which received Purina Rat Chow ${ }^{T M}$. Any differences found among the three groups of animals may then help to explain some of the pathology associated with the Wernicke-Korsakoff disease. 
METHODS

\section{Animals}

Forty-two male Sprague-Dawley rats were purchased from Simonsen Laboratories (Gilroy, California) and maintained in the animal facilities at San Jose State University. The rats were on a 12:12 hour light/dark cycle and kept at an average temperature of $75^{\circ} \mathrm{F}$. The animals were litter-mates, six weeks old, and weighed between 191-205 grams upon arrival.

All animals were placed into one of three diet groups: rats with similar body weights were paired and placed in one of two liquid diet groups while the remaining rats were maintained on a standard laboratory chow. The ethanol group received 100 milliliters per day of the Bioserv ${ }^{T M}$ Iiquid diet, containing $6.7 \% \mathrm{v} / \mathrm{v}$ of $95 \%$ ethanol (equal to $35 \%$ of the total calories). Their matched controls received the Bioserv ${ }^{T M}$ isocaloric liquid control diet in which sucrose provided equivalent replacement calories for the ethanol. The third group of animals consisted of those who could not be paired based upon their initial weight. This group was given unlimited Purina Rat chow ${ }^{\mathrm{TM}}$ and water.

All rats were housed in plastic cages with a wire grid top. The animals on liquid diets were housed individually, while the chow fed animals were housed in pairs. 
During the first three months of the study, the weight of each animal was recorded bimonthly. For the remainder of the study, a monthly recording of weights were obtained. From this data, average weight gains and percent weight gains for the three study groups were calculated. Diet Preparation

The two Bioserv TM liquid diet formulas used were 1) \#F1264 Liquidiet, Rat Diet Control (LD) and 2) \#F1267 Liquidiet, Rat Diet High Protein-Ethanol (EtoH). The diet formulas came in powder form and were kept frozen until needed. Fresh rehydrated diet was prepared every two days. The Liquidiet control was prepared in two 1.45 liter batches. Each batch was composed of 371 grams of the ID formula plus 1189 milliliters of distilled water. The EtOH diet, also prepared in two 1.45 liter batches, was composed of 241 grams of the EtoH formula, 1218 milliliters of distilled water and 97 milliliters of 200 proof Gold Seal Alcohol. Each batch was individually blended in a oster ${ }^{R}$ Commercial blender for 60 seconds. One half of each diet was refrigerated in a glass Erlenmeyer flask with a rubber stopper until used the following day. The remaining 1.45 liters of each diet was fed to the rats. The diet volumes were prepared based on the assumption that the animals would consume all 100 milliliters of their given diet daily; 
however, actual consumption of the ethanol diet did fluctuate, particularly in the early weeks of the study. The ethanol-fed animals were allowed to adapt slowly to their diet over a period of 7 days. This involved feeding the rats a diet composed of 2/3 LD and 1/3 EtoH for the first three days and during the next 4 days, $1 / 3$ LD and $2 / 3$ EtOH. On the eighth day (and for the remainder of the study), the rats received $100 \%$ of the EtoH diet (100 milliliters per animal).

Diet Consumption

Bioserv $^{\text {TM }}$ glass 100 milliliter graduated feeder tubes were utilized to administer the liquid diets. The wire cage tops were modified so that feeder tubes were suspended securely into each cage.

Daily, the feeder tubes were removed from the cages and the amount of diet consumed during the previous day was recorded for each animal. The tubes were thoroughly washed in hot water with Alconox ${ }^{\mathrm{TM}}$ soap and rinsed with distilled water. The rats receiving EtOH were given 100 milliliters of diet daily. The rats receiving the isocaloric control diet were pair-fed with the EtOH animals according to the technique developed by Lieber, et al., (1963).

On the first day of the experiment, all of the animals received 100 milliliters of their proper diet. The 
following day, when the amount of diet consumed was recorded and the new diet distributed, the EtOH animals received 100 milliliters, while the ID animals received the same amount as their EtoH partner had consumed the previous day. The use of the isocaloric control diet allowed the alcohol to be the single etiological agent present and removed all nutritional deficiencies as a factor.

Perfusion

Following 159 days of diet consumption, the animals were sacrificed. Each animal was anesthetized with an intraperitoneal injection of Sodium Nembutal, with the average dosage per animal being $0.674 \mathrm{cc}$. The depth of anesthesia was confirmed by the absence of a reflex withdrawal when a hind leg was pinched.

Following sufficient sedation, each animal was placed on a dissection tray ventral side up with its limbs secured. A midline incision was made in the upper abdomen and through the thoracic cavity, exposing the heart. A small incision was made in the right ventricle and another in the left ventricle. The right ventricle drained freely, while a canula was placed through the incision in the left ventricle and clamped into place with a hemostat. Without delay, the fixative (composed of $4 \%$ Paraformaldehyde, $1 / 4$ saturated Picric Acid, $0.1 \mathrm{M}$ Sodium Cacodylate, and $0.05 \%$ Calcium 
Chloride at a pH of 7.4) was delivered through the canula from the Perfusion Apparatus set at the systolic pressure of the animal, $120 \mathrm{~mm}$ of mercury. Signs of adequate perfusion included blanching of the liver, expansion of the intestines, stiffening of the muscles, and the flow of the yellow Picric fixative from the right ventricle incision. When the perfusion was determined to be complete, the line from the perfusion apparatus was clamped and the canula was removed. The head of the animal was decapitated using a guillotine and the brain was removed from the cranium. The brain tissue was placed in fresh fixative and kept at $4^{\circ} \mathrm{C}$ overnight to permit complete fixation.

The following day, the fixative was rinsed from the tissue using running tap water for two hours. The fully fixed specimens were then stored at $4^{\circ} \mathrm{C}$ in water until the sections were prepared.

Immunocytochemistry

Four regions of the brain were isolated and blocked: the frontal cortex, cerebellum, mammillary bodies, and the periaqueductal gray. The frontal cortex, used in this thesis, was sectioned using a McIlwain tissue chopper TM (The Mickle Laboratory, Engineering Co, LTD). The sections ranged in thickness from 100 to 150 microns. Specimens were placed in culture tray wells containing $0.1 \mathrm{M}$ phosphate- 
buffered saline (PBS) at a $\mathrm{pH}$ of 7.4. The sections underwent three 20 minute washes of PBS. The PBS buffer was then replaced with 1:100 rabbit antisera directed against rat liver alcohol dehydrogenase (ADH) previously prepared at the Alcohol Research Center, UCLA School of Medicine, Los Angeles, California (Kerr, et al., 1989). The tissue was allowed to incubate at room temperature for 2 hours, refrigerated for 20 hours, and then returned to room temperature for 2 hours. During room temperature incubation and for all the remaining steps in the procedure, the trays were placed on a rotating table to insure the constant mixing and penetration of solution into the tissue.

A modification of Sternberger's Peroxidase-Antiperoxidase method of immunocytochemistry (sternberger, et al., 1974) was employed. The tissue sections were washed for 1 hour in PBS (three changes) and then incubated in $3 \%$ Normal Goat Serum for one hour. Following a 1 hour wash in PBS, specimens were placed in Goat anti-rabbit gamma globulin at 1:20 (Cappel) for 2 hours. This was followed by another 1 hour wash with PBS (three changes) and then use of Peroxidase anti-peroxidase at 1:100 (Cappel) for 1 hour. Next, two changes of PBS was followed by 20 minutes in $0.05 \mathrm{M}$ Tris buffer at a $\mathrm{pH}$ of 7.6 . Then a 0.18 dilution of 3,3' diaminobenzidine tetrahydochloride (DAB) (Sigma) 
containing $0.0015 \%$ Hydrogen Peroxide was utilized for 2 hours. The reaction of the tissue with the DAB was stopped with a 1 hour wash in Tris buffer (three changes). The sections were then stored overnight at $4^{\circ} \mathrm{C}$.

\section{Slide Preparation}

The tissue sections were mounted on clean, glass histological slides using a 1:4 dilution of egg albumin. The albumin was collected from fresh eggs. The tissue sections were positioned in a droplet of the egg albumin using a soft brush to prevent tearing the tissue. The slides were permitted to dry on a warming table at $39^{\circ} \mathrm{C}$ for 24 hours. The sections were then dehydrated in three changes of industrial grade $100 \%$ ethanol and cleared in three changes of 1008 xylenes. Without allowing the sections to dry, Permount ${ }^{T M}$ was applied and coverslips placed in position.

The slides were labeled randomly in a fashion that allowed the procedure to be completed in a non-biased manner.

Viewing and Photography of the Tissue

The tissue was inspected and photographed using an Olympus $^{\text {TM }}$ BH Photomicrographic system with Kodak ASA 200 Color Print Film. The 10x objective was used for all of the photos taken for digitizing. An exposure meter set to 
D-Type (Daylight) Color Temperature Regulation was used to confirm the exact exposure time of each photo. All photographs processed for cell density calculations measured 3.25 by 5 inches, with the total print magnification being $80 x$.

\section{Cell Density Calculations}

The cell density in each photo was measured by counting stained neurons (those containing $A D H$ ) and dividing by the true tissue area. The tissue area $\left(\mathrm{mm}^{2}\right)$ and neuron counts were measured with a digitizing tablet and morphometric software (SigmaScan TM-Jandel Scientific Inc.). True tissue area was defined as the tissue area in the photograph that could potentially contain ADH neurons, minus the negative tissue areas (blood vessels, tears, etc.). The neuron density was defined as the number of stained neurons, per square millimeter of true tissue area. Plate 1 shows a photograph accompanied by a computer printout of the true tissue area, negative tissue area and the location of the ADH-containing neurons within that specific tissue area.

Once the photographs had been digitized, the code that had been used to prevent any bias calculations was uncovered. A mixed model nested analysis of variance (ANOVA) (Sokal and Rohlf, 1981) was then used to compare neuron density among the three diet groups. Animals were 


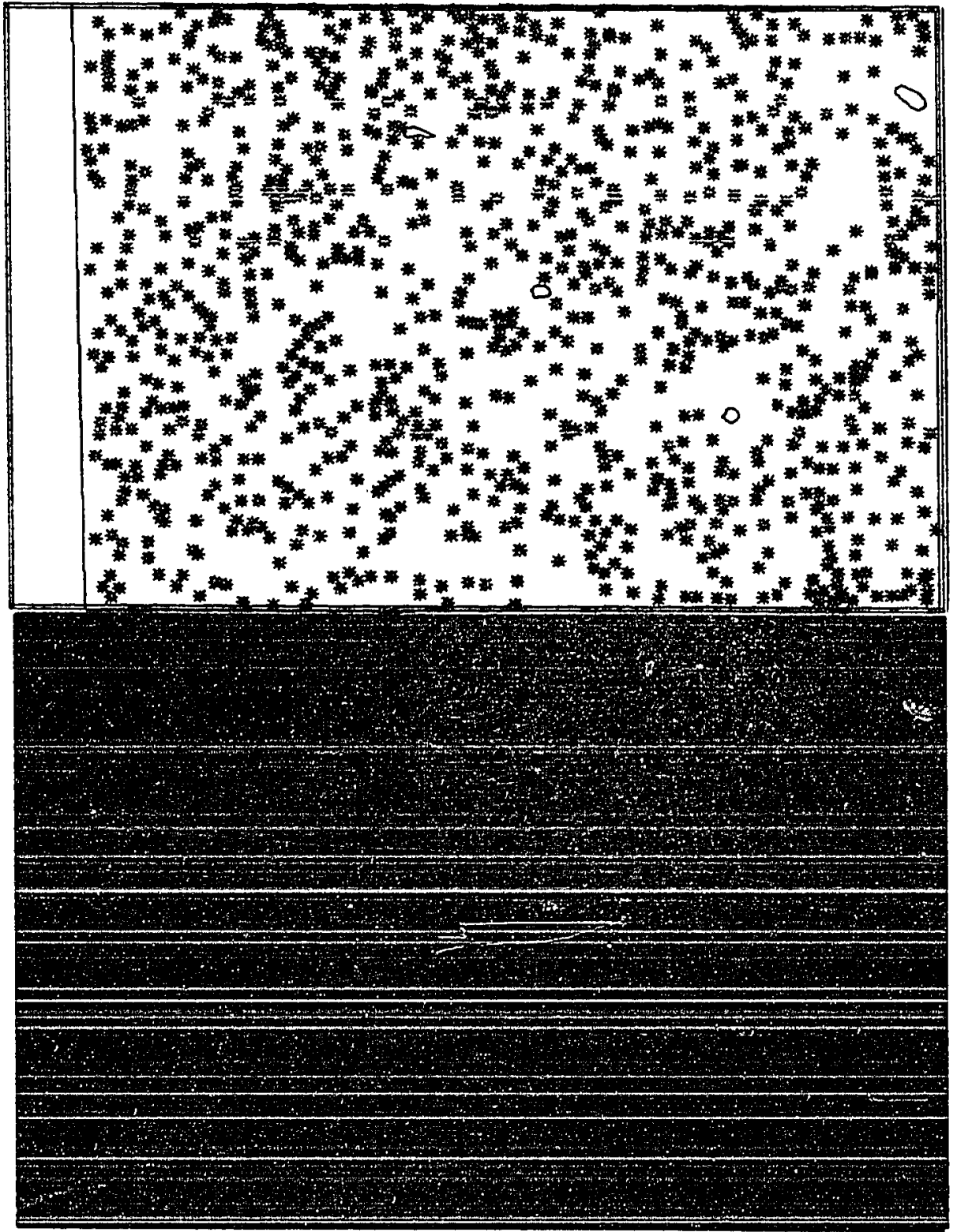

Plate 1: Computer generated analysis for the location of ADH-containing neurons in the cerebral cortex of a liquid diet control animal. 
nested within diet groups and photographs were nested within animals. 


\section{RESULTS}

\section{Animal weight Gain}

The purpose of recording the average weight gain and the percent weight gain of the animals was to determine if there was a correlation between the weight gained or lost by the animals and the ADH-containing neuronal density of the cerebral cortex. Initial average weight of the LD animals and EtOH animals was 207.74 grams and 191.15 grams respectively (Table 1). The EtOH animals had the lowest average weight of the three diet groups prior to day 105. Beyond day 105, the average weight was equivalent to that measured in the other two diet groups.

The percent weight gain between the ID and EtoH animals appeared to be similar. Similarities were expected because the EtOH and the ID animals were receiving the same number of calories based or the pair-feeding procedure employed in this study. During the course of the study, it was observed that the Iiquid diet animals seemed to consume their diet more rapidly then their alcoholic counterparts (these findings followed similar observations made by Lieber and Decarli, 1989). Despite the rapid consumption of diet all three experimental groups increased their average weight by over 100 per cent though the duration of the study. Immunocytochemistry

There was some contamination evident in various 
TABLE 1:

AVERAGE WEIGHT IN GRAMS AND PERCENT WEIGHT

GAIN FOR EACH DIET GROUP DURING THE 159 DAY STUDY.

Diet Group

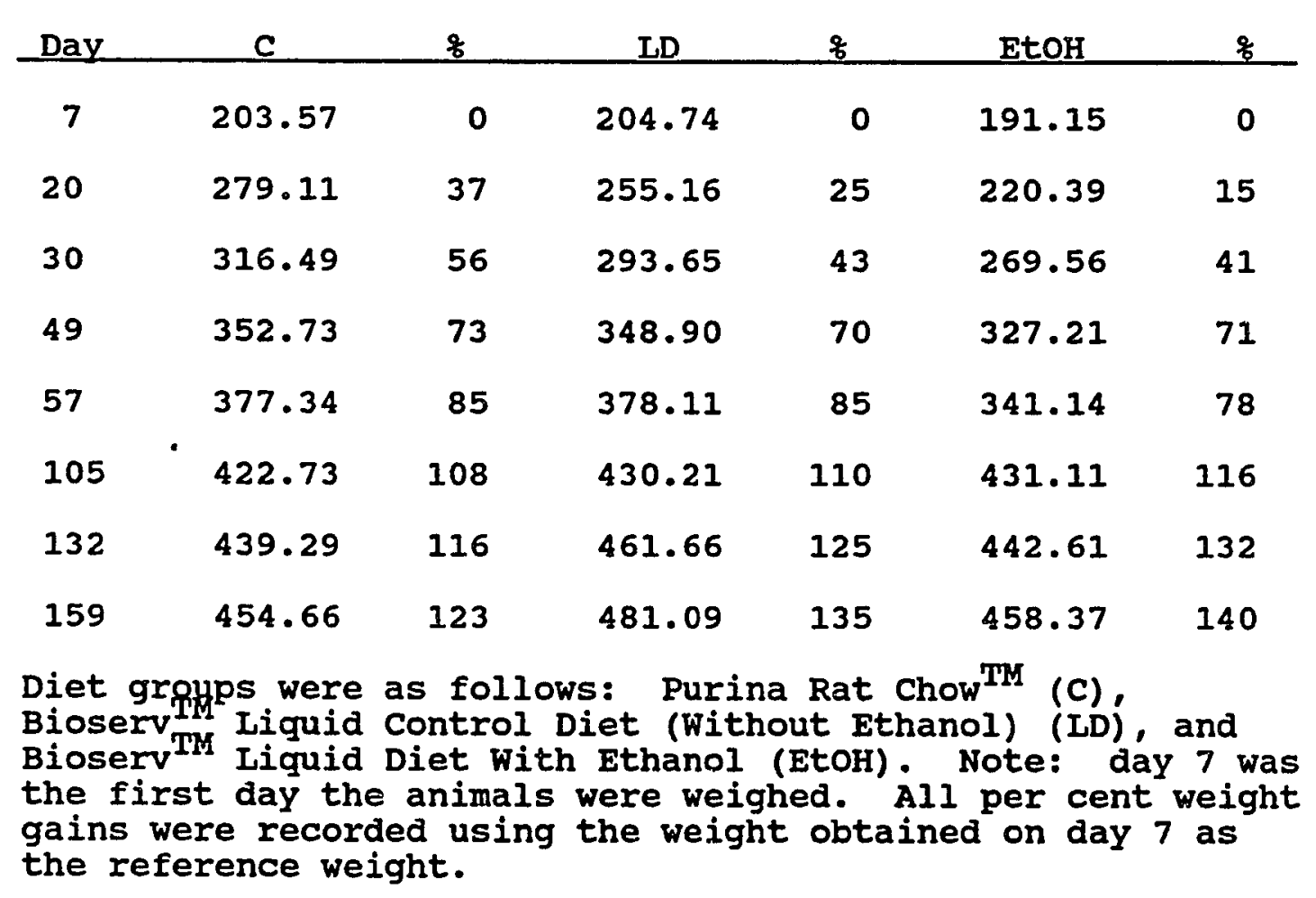


specimens following the first immunocytochemistry procedure and a second batch of sections had to be run.

Control checks were used following tissue exposure to the preimmune serum to look for non-specific neuronal staining. Following this procedure, there was evidence of stain in the walls of the capillaries located in all of the control tissue sections. The normal presence of peroxidase in the cells of the vessel walls reacts with the hydrogen peroxide of the immunocytochemistry procedure to cause the vessel walls to stain a brown color (Plate 2). From the evidence of the immunocytochemical stain in the vessel walls and the absence of stained neurons in the tissue sections, it could be concluded that the reagents used in the immunocytochemistry process were not contaminated.

\section{Cell Density}

Shown in Plate 3-5 are photographs which represent the three diet groups. The number of neurons present in the photograph and the mean neuron density for all animals in a diet group is displayed beneath the photo.

The nested analysis of variance indicated that there were no statistically significant differences among the three diet groups (Table 2). Therefore, the average

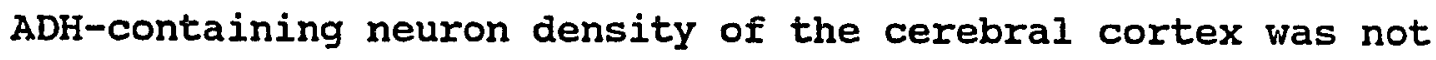
affected by the type of diet the rats received. 


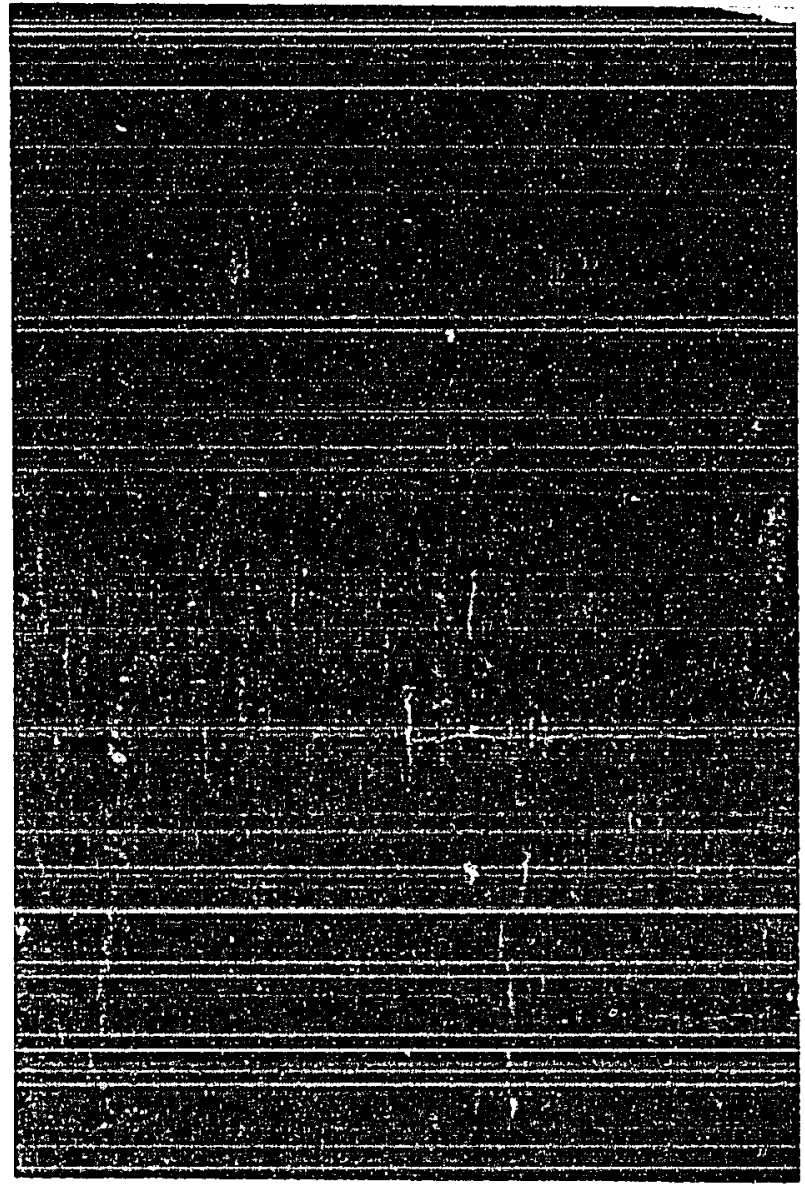

Plate 2: Cerebral cortex - Preimmune serum on a liquid diet control section. 


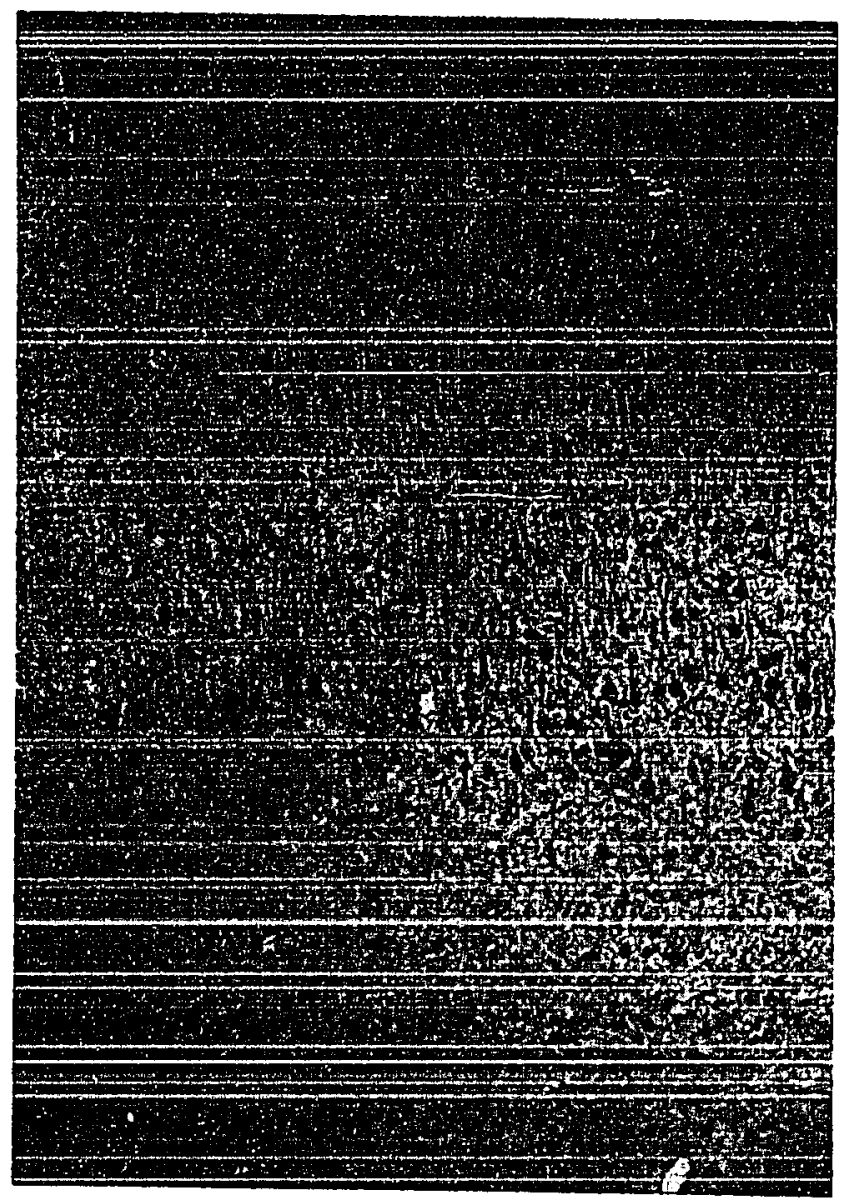

Plate 3: Cerebral cortex - liquid diet control. 125x. 907 neurons. Density is equal to 1152.152 cells $/ \mathrm{mm}^{2}$. $(\rightarrow)$ = dendrites. 


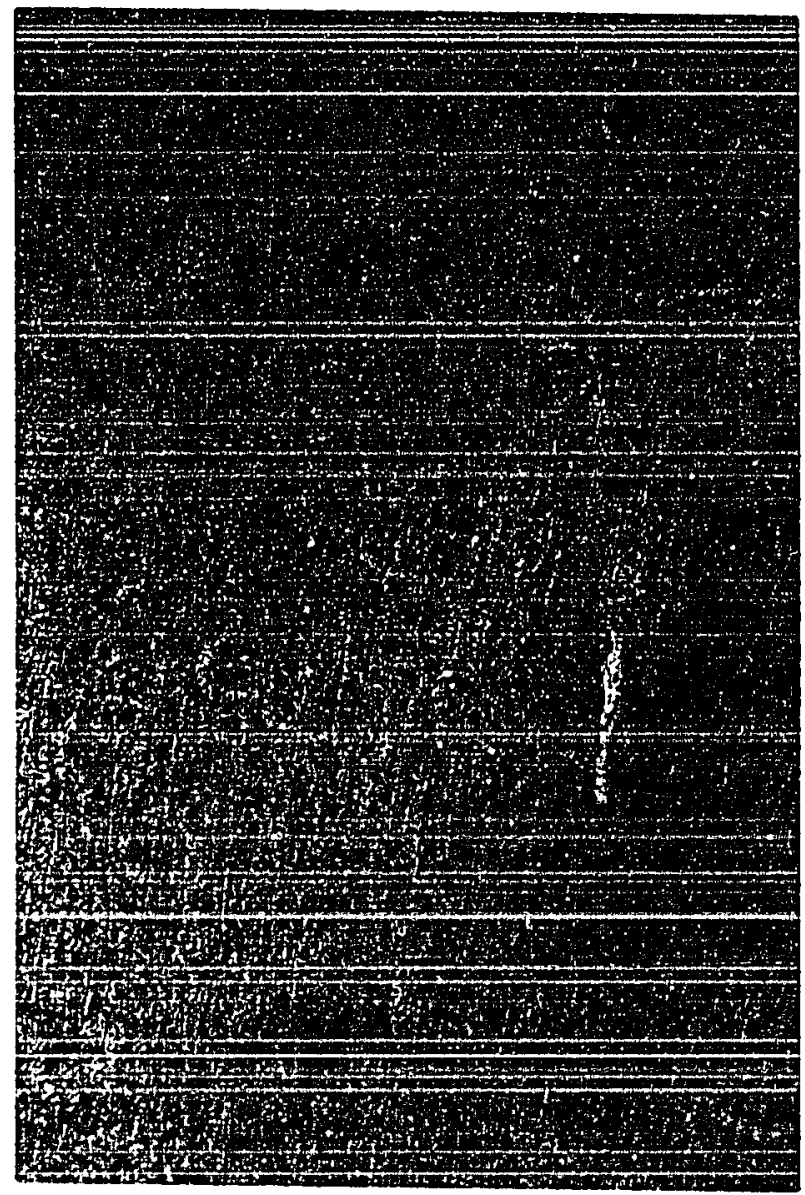

Plate 4: Cerebral cortex - ethanol Iiquid diet. 125x. 813 neurons. 2 Density is equal to 1098.492 cells / $\mathrm{mm}^{2}$. 


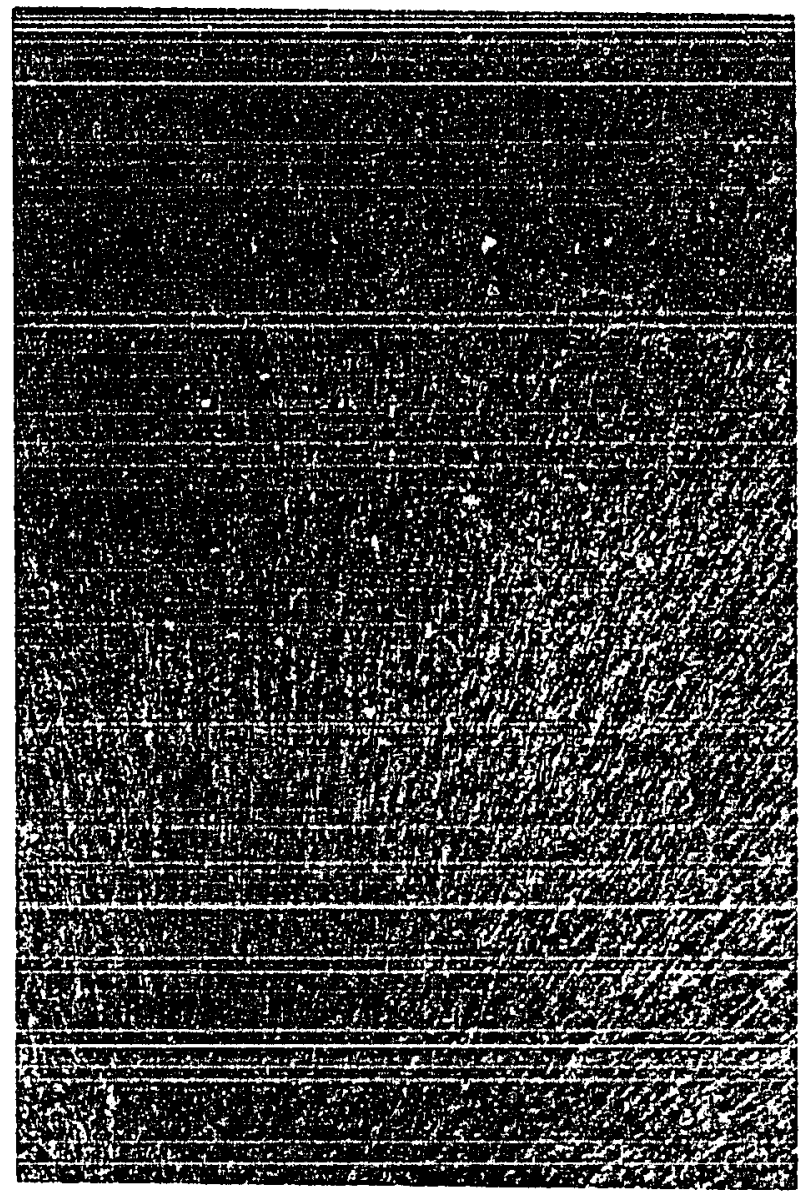

Plate 5: Cerebral cortex - Chow control diet. 125x. 1106 neurons. Density is equal to 1332.143 cells $/ \mathrm{mm}^{2}$. 


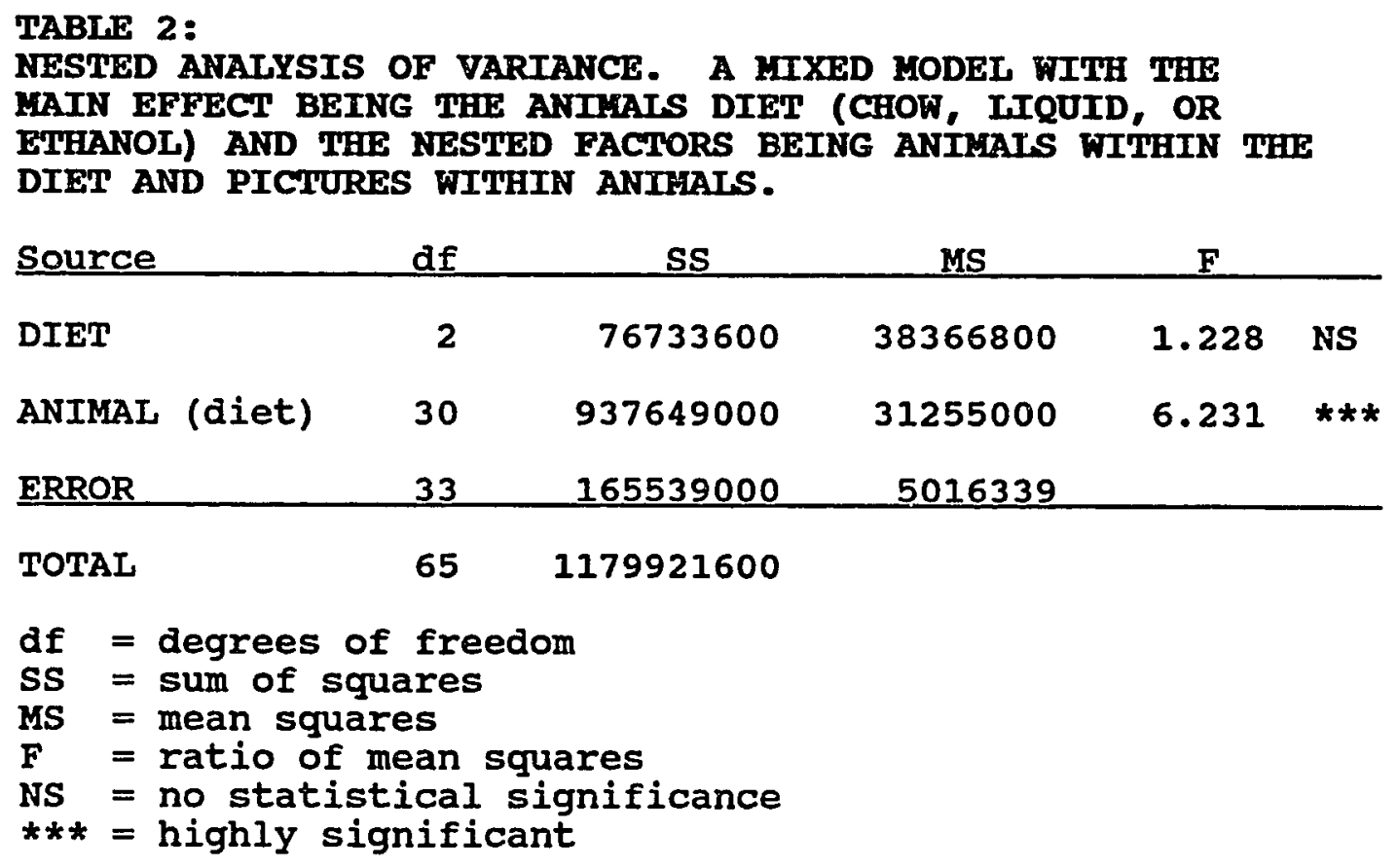




\section{ADH-Containing Neurons}

Neurons staining for the presence of ADH can be located in all six layers of the cerebral cortex. Neurons staining for the presence of $\mathrm{ADH}$ are found adjacent to non-stained neurons, so it seems that $\mathrm{ADH}$ is specific to certain cerebral neurons.

Stained neurons did not appear in the white matter of the brain. These observations were supported in a previous investigation by Kerr, et al., (1989a) using the same experimental technique, but following an acute administration of ethanol. An additional finding also supported by Kerr's acute study is the presence of ADH in the nerve cell bodies and dendrites of the ADH-containing cells. Stained dendrites are clearly marked in Figure 5.

A finding, not previously documented but discovered in this study, is the presence of ADH in the axons of some of the ADH-containing neurons in the cerebral cortex. The ADHcontaining axons were found in all three diet groups. It is not known whether all of the ADH-containing neurons of the cerebral cortex show $A D H$ in their axons. In this study, ADH-containing axons were most easily found in Betz cells (giant pyramidal cells) of the internal pyramidal layer of the cerebral cortex. The large size of these cells, in relation to the other neuron types of the 
cerebral cortex, made the identification of their ADHcontaining axons easy with the $40 \mathrm{x}$ objective of the microscope (Plate 6). 


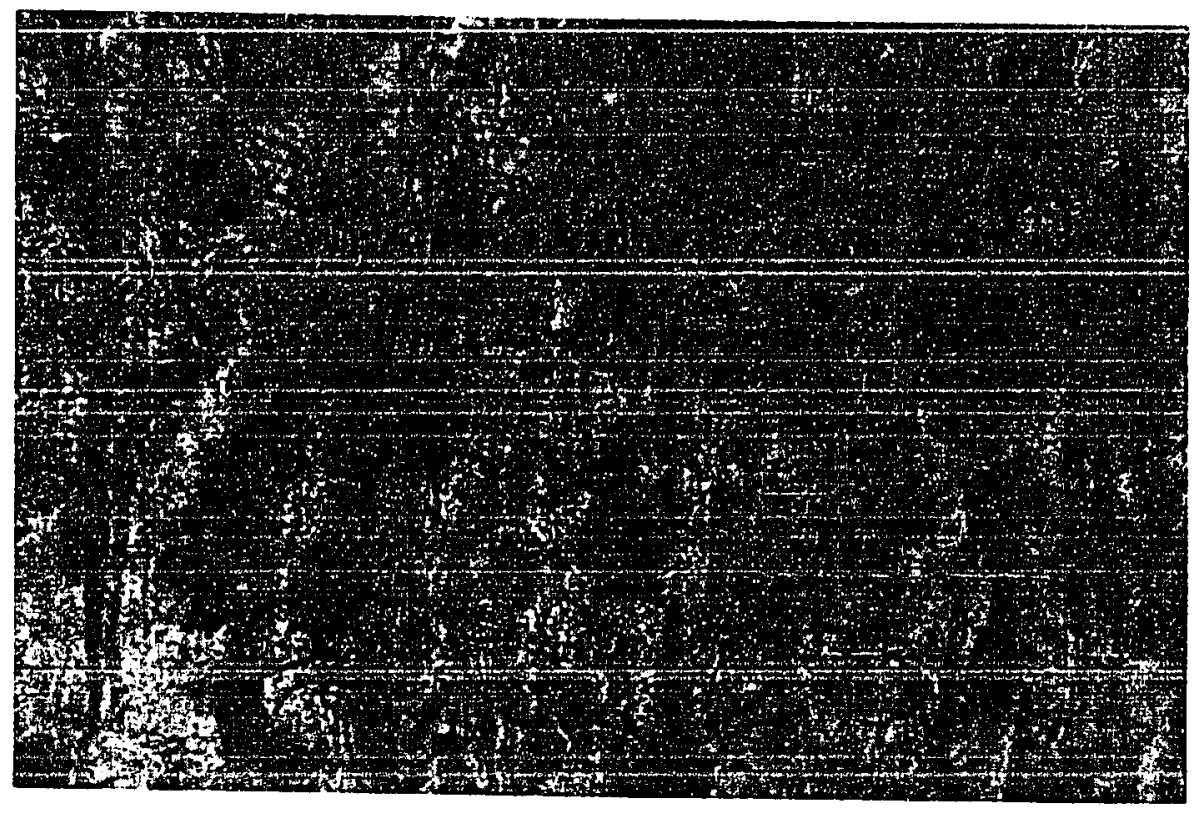

Plate 6: Cerebral cortex - ADH-containing axon of an ADH-containing Betz cell. $(\rightarrow)=$ axon. 


\section{DISCUSSION}

From this study, it can be concluded that chronic alcohol exposure does not affect the density of ADH-containing neurons in the prefrontal and premotor segments of the cerebral cortex. The liquid diet pair-feeding technique employed was used to rule out vitamin or mineral deprivation as a cause in neuronal difference. If a difference of neuron density in the cerebral cortex had occurred, alcohol could be isolated as the single direct etiological agent responsible for the neuronal changes.

A hypothesis that may account for the similar neuronal densities, in the cerebral cortex of the three diet groups, proposes that there is a rise and fall of the number of ADHcontaining neurons. An acute study conducted by Kerr, et al. (1989b), using the same experimental technique, revealed an increase in the density of neurons in the cerebral cortex, by approximately 25 neurons per square millimeter in alcohol consuming animals. This may represent the ascending phase of a bimodal curve in the ADH-containing neuron density. The present study (159 days), which shows no difference in neuron density, may represent the leveling off of the curve following its descent back to the pre-exposure levels. An experimental way to test the proposed theory would be to shorten the duration of the study to various 
time intervals and then calculate the ADH neuron density. The discovery of $A D H$ in the axons of some ADH-containing Betz cells was significant to this study. It is known that cell axons are not the site of protein production. Protein found in axons is produced in the cell body and then transported into the axons. With the discovery of $\mathrm{ADH}$ in Betz cell axons, further information needs to be obtained regarding the transport of $A D H$ into the axon. It may be that there is a specific carrier protein which binds to the enzyme and takes it from the cytoplasm of the soma into the axon via cytoplasmic streaming. Future research needs to focus on discovering an ADH-carrier protein in the ADH-containing neurons of the cerebral cortex.

Locating $A D H$ in neuronal axons also showed that, following the ingestion of alcohol, acetaldehyde production is occurring in the axon as well as in the dendrites and nerve cell body. The production of acetaldehyde increases the probability that this toxic byproduct of ethanol metabolism will interfere with the synapses associated with the axons and dendrites.

Acetaldehyde is capable of inhibiting or altering the synaptic impulses between the dendrite-axon junctions. This action will effect the proper brain function which may 
result in memory loss, clouding of perception and judgement, dementia, ataxia, and/or oculomotor abnormalities (Schuckit, 1984). If synaptical impulses are completely blocked, neuronal death will occur. Another cell type that can also be affected by toxic doses of acetaldehyde is the glial cell. With a reduction of neurons and/or glial cells, the tissue will atrophy. Tissue atrophy of the cerebral cortex is often found in Wernicke-Korsakoff patients utilizing a CAT scan or at the time of autopsy.

Assuming continued alcohol consumption and the production of acetaldehyde in the neurons, another hypothesis that can be tested by shortening the duration of the study is the theory that the increase of ADH-containing neurons in the frontal cortex may rise and then reach a plateau. During a plateau state, the amount of acetaldehyde produced may be too large to be reduced to acetate (a non-toxic byproduct) by acetaldehyde dehydrogenase. The toxic effects of increasing levels of acetaldehyde may cause cell damage and/or cell death. If this theory is true, then the cells counted in this study may be all that remain of the active ADH-containing neurons. However, it must be considered that the immunocytochemistry technique used in this study is a non-specific procedure used to stain for $A D H$. It has not been documented if the 
stained $\mathrm{ADH}$ is an active or inactive form. Thus, the cells counted in this study may be dead or dying celis. A biochemical study of $\mathrm{ADH}$ within the neurons could be used determine the enzyme activity.

During the investigation, various regions of the brain such as cerebellum, mammillary bodies, and periaqueductal gray were studied by other members of the laboratory team. Comparing the results of the four tissue areas, it has been determined that not all regions of the brain react to the alcohol in the same way. The acute study conducted by Kerr, et al. (1989b) revealed an increase in the mean neuronal density of approximately 25, 150, and 25 neurons per square millimeter in the cerebral cortex, mammillary bodies, and periaqueductal gray respectively in rats receiving ethanol. The greatest increase in neuron density was seen in the mammillary bodies which nearly doubled the number of neurons per square millimeter in comparison to the liquid diet control animals. In the cerebellum, the acute study showed a slight decrease in the neuronal density of approximately 5 neurons per square millimeter in rats receiving ethanol, compared to the animals on the isocaloric liquid diet (this may have been caused by the small sample size and limited number of countable neurons). 
The present chronic study showed some fascinating changes. The cerebral cortex, mammillary bodies, and periaqueductal gray regions did not show a statistical difference in the $\mathrm{ADH}$ containing neuronal density between the animals receiving alcohol and those on the isocaloric liquid diet. However, the cerebellum showed a remarkable difference when compared to the results obtained in the acute study.

The cerebellum, after chronic alcohol exposure, showed a mean increase in the density of ADH-containing Purkinje cells of approximately 525 neurons per square millimeter of tissue. Another finding was that the size of the Purkinje cells had decreased. In the chow fed group, the area of the Purkinje cells was randomly calculated as being $4.00 e^{-5}$, the Purkinje cells of the liquid control diet was $3.00 e^{-5}$, and the ethanol diet Purkinje cells had an area of $2.00 e^{-5}$. The comparison of the cerebellum of the three diet groups (LD, EtoH, and (how) showed that the LD and Chow control diets had a significant statistical difference in the density of ADH-containing Purkinje cells. A difference of Purkinje cell density in the LD animals shows the liquid diet is capable of causing structural changes in the cells of the cerebellum with chronic exposure. It is therefore essential, when performing the isocaloric pair-feeding 
procedure to use a chow-fed control group. This was a finding that had not previously been documented.

The discoveries regarding the cerebral cortex, mammillary bodies, cerebellum, and periaqueductal gray were presented in poster form at the 1990 Research Society on Alcoholism conference. Two abstracts explaining the findings have been published in the journal alcoholism: Clinical and Experimental Ressearch (Kerr, et al., 1990a; Kerr, et al., 1990b).

Alcohol studies will remain a part of biological research and of interest to the general public. Alcohol, whether illegal or legal, will always be present in society because of its mood altering affects which attract consumers. By continuing to study the effects of alcohol on the brain, we will someday be able to explain what is occurring biochemically and structurally following alcohol consumption. In time, the mysteries surrounding syndromes such as the Wernicke-Korsakoff syndrome will be answered and new question involving alcohol and its harmful effects will replace our current questions. 


\section{LITERATURE CITED}

Abel, E.L. 1982. Consumption of Alcohol During Pregnancy: A Review of Effects on Growth and Development of Offspring. Human Biology., 54:421-453.

Arendt, T., R. Marchbanks, and J.A. Gray. 1987. Effects of Prolonged Ethanol Consumption on Cholinergic Function in the Basal Forebrain and Memory. Biochem. Soc. Trans., 15:499-500.

Arendt, T., D. Hennig, J.A. Gray and R. Marchbanks. 1988. Loss of Neurons in the Rat Basal Forebrain Cholinergic Projection System After Prolonged Intake of Ethanol. Br. Res. Bull., 21:563-569.

Charness, M.E., R.P. Simon and D.A. Greenberg. 1989. Ethanol and the Nervous System. N. Engl. J. Med., 321: 442-454.

Courville, C.B. 1955. Effects of Alcohol in the Nervous System of Man. San Lucas Press, Los Angeles.

De Wardener, H.E., and B. Lennox. 1947. Cerbral Beriberi (Wernicke's Encephalopathy). Lancet, 1:11-17.

Duncan, J.S., J.E. Kline and I. Sokoloff. 1976. Identity of Brain Alcohol Dehydrogenase with Iiver Alcohol Dehydrogenase. Biochem. J., 153:561-566.

Goldstein, B., and D.S. Maxwell. 1982. The Purification and Immunocytochemical Iocalization of Rat Iiver and Kidney Alcohol Dehydrogenase. Alcohol clin. Exp. Res., 6:142. (abstr)

Inokuchi, T., K. Inoue, A. Aoyama and N. Hashizume. 1981. Effect of Ethanol Ingestion on Thiamine Metabolism: Clinical and Experimental studies. J. Nutr. Sci. vitaminol., 27:263-281.

Jacobson, E. 1952. The Metabolism of Ethyl Alcohol. Pharmacol. Rev., 4:107.

Jones, K.L., D.W. Smith, C.N. Ulleland and A.P. Streissguth. 1973. Pattern of Halformation in offspring of Chronic Alcoholic Mothers. Lancet, 1:1267-1271. 
Julia, P., D. Boleda, J. Farres and X. Pares. 1987. Mammalian Alcohol Dehydrogenase: Characteristics of Class III Isoenzymes. Alcohol Alcohol., Suppl. 1: 169-173.

Kerr, J.T., D.S. Maxwell and D.W. Crabb. 1989a. Immunocytochemistry of Alcohol Dehydrogenase in the Rat Central Nervous System. Alcohol. Clin. Exp. Res., 13:730-736.

Kerr, J.T., D.S. Maxwell and W.E. Bros. 1989b. Effects of Acute Alcohol Administration on the Immunocytochemistry of Alcohol Dehydrogenase. Alcohol. Clin. Exp. Res., 13:332. (abstr)

Kerr, J.T., พ. Bros, M. Cherry, S. Burns, and D. Maxwell. 1990a. Localization of Alcohol Dehydrogenase in the Laminae of the Motor Cortex. Alcohol. clin. Exp. Res., 14:303. (abstr)

Kerr, J.T., พ. Bros, S. Burns, M. Cherry, J. Kalousdian, R. Ruby, and D. Maxwell. 1990b. Alcohol Dehydrogenase Distribution in the cNs Following Chronic Alcohol Administration. Alcohol. clin. Exp. Res., 14:303. (abstr)

Kissin, B., and H. Begleiter. 1983. The Pathogenesis of Alcoholism Biological Factors. Plenum Press, New York, p. 600-601.

Korsten, M.A., S. Matsuzaki, L. Feinman and C.S. Lieber. 1975. High Blood Acetaldehyde Ievels After Ethanol Administration. N. Engl. J. Med., 292: 386-389.

Lieber, C.S., D.P. Jones, J. Hendelson, L.H. DeCarli and C.S. Daciason. 1963. Fatty Liver, Hyperlipemia and Hyperuricemia Produced by Prolonged Alcohol Consumption, Despite Adequate Dietary Intake. Trans. Asso. Amer. Phy , 76:289-300.

Lieber, C.S. 1983. Interactions of Alcohol and Nutrition. Introduction to a Symposium. Alcohol. Clin. Exp. Res., z:1-3.

Lieber, C.S., and I.M. DeCarli. 1989. Liquid Diet Technique of Ethanol Administration: 1989 Update. Alcohol Alcohol., 24:197-211. 
Majchrowicz, E., and E.P. Noble (ed.). 1979. Biochemistry and Pharmacology of Ethanol. Vol 1. Control of Ethanol Oxidation and Its Interaction with other Metabolic Systems. J.J. Higgins (author). Plenum Press, New York, p. 249-254.

McCandless, D.W., A.D. Curley and C.E. Cassidy. 1976. Thiamin Deficiency and the Pentose Phosphate Cycle in Rats: Intracerebral Mechanisms. J. Nutr., 106:1144-1151.

Mendelson, J.H., and N.K. Mello. 1979. Biologic Concomitants of Alcoholism. N. Engl. J. Med., 301: $912-921$.

Neville, J.N., J.A. Eagles, G. Samson and R.E. Olson. 1968. Nutritional status of Alcoholics.

Am. J. Clin. Nutr., 21:1329-1340.

Raskin, N.H., and I. Sokoloff. 1970. Alcohol Dehydrogenase Activity in Rat Brain and Liver. J. Neurochem., 17: $1677-1687$.

Ron, M.A. 1982. Syndromes of Alcohol-Related Brain Damage. Brit. Med. Bull., 38:91-94.

Schenker, S., G.I. Henderson, A.M. Hoyumpa, and D.W. McCandless. 1980. Hepatic and Wernicke's Encephalopathies: Current Concepts of Pathogenesis. Amer. J. Clin. Nutr., 33:2719-2726.

Schreiber, S.S., H. Oratz, M.A. Rothschild, F. Reff and C. Evans. 1974. Alcoholic Cardiomyopathy II. The Inhibition of Cardiac Microsomal protein Synthesis by Acetaldehyde. J. Mol. Cell. Cardiol., ㅇ: 207-213.

Schuckit, M.A. 1984. Drug and Alcohol Abuse. A Clinical Guide to Diagnosis and Treatment. Plenum Press, New York, p. 44-66.

Sokal, R.R., and F.J. Rohlf. 1981. Biometry. W.H. Freeman and Company, New York.

Sokoloff, L. 1977. Relation Between Physiological Function and Energy Metabolism in the Central Nervous System. J. Neurochem., 29:13-26. 
Sternberger, L.A. 1974. Immunocytochemistry. Prentice-Hall, New Jersey, p. 129-171.

Tabakoff, B., and J.P. von Wartburg. 1975. Separation of Aldehyde Reductases and Alcohol Dehydrogenase From Brain by Affinity Chromatography: Metabolism of Succinic Semialdehyde and Ethanol. Biochem. Biophys. Res. Comm., 63:957-966.

Thomson, A.D. 1978. Alcohol and Nutrition. Clinics in Endocrinology and Metabolism, 7:405-428.

Thomson, A.D. 1982. Alcohol-Related structural Brain Changes. Brit. Med. Bull., 38:87-91.

Thomson, A.D., P.R. Ryle and G.K. Shaw. 1983. Ethanol, Thiamine and Brain Damage. Alcohol Alcohol., 18:27-43.

Victor, M., R.D. Adams, and G.H. Collins. 1971. The Wernicke-Korsakoff syndrome. F.A. Davis Company, Philadelphia.

Wallgren, H. 1966. Effects of Alcohol on Biochemical Processes in the Central Nervous System. Psych. Med., 28:431-442.

Westcott, J.Y., H. Weiner, J. Shultz and R.D. Myers. 1980. In vivo Acetaldehyde in the Brain of the Rat Treated with Ethanol. Biochem. Pharm., 29:411-417.

Zeiner, A.R., A. Paredes, and H.D. Christensen. 1979. The Role of Acetaldehyde in Mediating Reactivity to an Acute Dose of Ethanol Among Different Racial Groups. Alcoholism., 3:11-18. 